\title{
College Student Perception to College Quality of Life: A Constructivist Grounded Theory Study
}

\author{
Rahmah Hastuti $^{1 *}$ Yohanes Budiarto $^{1}$
}

\author{
${ }^{1}$ Psychology Faculty of Universitas Tarumanagara, Jakarta, Indonesia \\ *Corresponding author.Email: rahmahh@fpsi.untar.ac.id
}

\begin{abstract}
This study aims to analyze the dynamics of student life in Jakarta based on a constructivist grounded theory approach. Measurements are made through testing the aspects contained in the variable construct of college quality of life or college life for students. This study identified several themes whose main purpose was to assess the contribution of aspects of the dynamics of college life to students in Jakarta. Data collection was done by using a convenience sampling technique. This type of sampling is non-probability sampling. This sampling technique is based on the availability of available participants. The selection of this sampling technique is based on considerations of the characteristics of the general population, the efficiency of time and energy in conducting research. The research was conducted on 213 students in Jakarta. Data collection was carried out in February 2020. The results showed that college life quality of college student in Jakarta included six themes. Thus, the quality of college life is related to various things that are not only about scientific and academic knowledge but also contained social aspects of student college life.
\end{abstract}

Keywords: College quality of life, constructionist approach, college student

\section{INTRODUCTION}

Every human being is obliged and has the right to receive an education because from education, a person obtains knowledge [1]. Based on the Law of the Republic of Indonesia No. 20 of 2003 concerning the Education System ("Government of the Republic of Indonesia", 2003) explains that education is a conscious and planned effort to create an atmosphere of learning and the learning process so that students actively develop their potential to have religious spiritual strength, self-control, personality, intelligence, noble character, and skills needed by himself, society, nation and state. The level of formal education in Indonesia consists of basic education, secondary education and higher education. Before discussing constructs and measures of quality of life in higher education on campus, it is necessary to distinguish between three types of studies involving students and quality of life: (a) studies examining the relationship between student quality of life and factors such as personality, health, and the environment, (b) studies to develop the quality of life measures specifically adapted for students, and (c) studies to develop quality measures of student life. College or campus is an integral component of the life of a student, and thus the quality of life in college for students is an important part of the overall quality of life. Based on the bottom-up spillover theory, one of the subdomains in the quality of life of students, namely the quality of college life, can affect the overall quality of life [2].

\section{BACKGROUND}

The literature on the dynamics of student college life is very broad and is based on various measurements with different approaches. The operationalization of the variables is emphasized on various responses regarding aspects of satisfaction with the quality of student's life. Benjamin argues that students struggle to meet the academic requirements in order to get a degree but at the same time students are also required to fulfill the wishes of their parents, friends, and other relatives. In addition, students can also experience conflicts in life related to health and financial conditions at unexpected times. Therefore, the handling carried out by students to overcome various problems varies. Understanding the complexities of the quality of life of students has become essential for universities to plan their expenditures efficiently [3]. Research was conducted in Turkey by Arslan and Akkas, which conducted a model test used to assess campus life satisfaction and evaluate the overall impact on the quality of campus life (social, academic, and service satisfaction), life satisfaction, and identification. The study also assessed the impact of university academic programs, social life, facilities, and services on the college quality of life of students in this sample in relation to similar studies from Turkey and other countries. The survey that had been conducted involved 1,260 students who attended public universities in Turkey. The measurement tools include the quality of the campus life scale (QCL), the satisfaction with the campus life scale, the identification satisfaction scale 
with the life scale and the form of personal information. The results show social satisfaction has the strongest positive impact on QCL [4]. The description of the quality of college life for students is one of the feedbacks for students and universities toreview student experiences and the results obtained by students while students are at the tertiary level. According to Elliott, the quality of college life in students is determined by several main factors, including the sense of belonging to the student and the quality of education provided by the college. In addition, the increase in the quality of college life is also influenced by interactions with faculty who are able to provide wellstructured and fair instructions [5]. Sirgy et al. argued that several aspects that could affect the quality of college life consisted of student satisfaction with social, academic and university facilities [2]. Another research conducted by Yang and Fan [6], states that the quality of life of students is a priority in many universities. Their research was conducted to investigate the effect of quality of life on learning in tertiary institutions among Chinese students at Uncle Sam State University, particularly at National Quemoy University, Taiwan, using a questionnaire and interview techniques. The quantitative data collected revealed that 311 college participants who were randomly selected felt a $70.5 \%$ influence on quality of life and academic growth on a scale of 0 to 100 . Furthermore, the qualitative data collected showed that students viewed quality of life as important for learning achievement. and their academics, and various aspects of life such as sleep quality or diet, peer relationships, or time management, were shown to interact in influencing their learning. Next, Schibeci's research [7] found a relationship between academic achievement and student attitudes towards science. Martin et al. [8] argued that the perceptions of early adult individuals, including those who became students of higher education institutions, were significantly influenced by their first impressions of higher education, such as tuition fees, facilities, the environment where they live around the college, material presented by lecturers, and so on. On the other hand, according to Wilder, the attitudes and perceptions of students towards higher education can have an effect on determining the level of student resilience in higher education. However, if the attitudes and perceptions of students tend to be negative, then the students are likely to drop out of college. The main factor that causes the formation of attitudes and perceptions is the sense of inequality that students feel about the interaction between lecturers and students.

\section{METHOD}

\subsection{Participant}

This research is qualitative survey research or constructionist approach philosophy, which seeks to explain education can have an effect on determining the level of student resilience in higher education. However, if the attitudes and perceptions of students tend to be negative, then the students are likely to drop out of college. The main factor that causes the formation of attitudes and perceptions is the sense of inequality that students feel about the interaction between lecturers and students and find variations in the research variables in the population under study. Usually, the characteristics of the research are openended questions, emerging approaches, text and / or image data. The characteristic of the constructionist approach is that the researcher positions himself as a researcher in the context of research, collects the meaning produced by research participants, focuses on a concept or phenomenon, brings personal values into research, studies the context or background of research participants, interprets data, engages the researcher in collaborate with research participants. The measuring instrument in this study was designed to measure the dynamics of student college quality of life. The number of participants in this study was 213 people, age $(M=19.23 ; S D=.778)$. Participants consisted of 32 men and 181 women.

Table 1 Demographic data of participants by age

\begin{tabular}{crr}
\hline Age & Frequency & Percentage $(\%)$ \\
\hline 18 & 19 & 8,9 \\
19 & 144 & 67,6 \\
20 & 37 & 17,4 \\
21 & 8 & 3,8 \\
22 & 4 & 1,9 \\
23 & 1 & 0,5 \\
\hline Total & 213 & 100,0 \\
\hline
\end{tabular}

The following table contains the demographic data of study participants related to gender. In summary, it can be seen in table 2 .

Table 2 Demographic data participants based on sex

\begin{tabular}{lrr}
\hline Sex & Frequency & Percentage (\%) \\
\hline Man & 32 & 15,0 \\
Woman & 181 & 85,0 \\
\hline Total & 213 & 100,0 \\
\hline
\end{tabular}

\section{FINDINGS AND DISCUSSION}

Thematic related research findings college climate is a measure of the real or perceived quality of interpersonal, academic, and professional interactions on campus and consists of the attitudes, behavior, and standards of faculty, staff, administrators, and students regarding the level of appreciation for individual needs, abilities, and potential [9]. Based on the thematic analysis, it was obtained six thematic quality of student life in Jakarta as summarized in the following figure. 


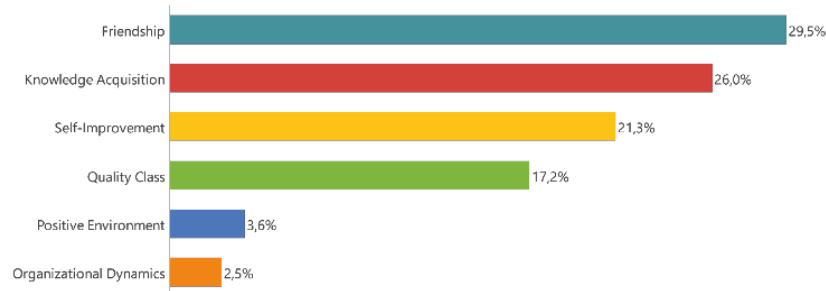

Figure 1 Thematic description of the college quality of life in Jakarta.

Based on the thematic analysis of the quality of college students in Jakarta, the following findings were obtained:

(a) friendship is the most frequently experienced indicator of lecture quality, (b) knowledge acquisition, (c) selfdevelopment, (d) quality of lectures, (e) positive environment, and (f) organizational dynamics. Friendship is the most positive theme that students get during lectures $(29.5 \%)$, followed by the acquisition of knowledge in college life $(26 \%)$. Organizational dynamics is the least frequent theme of positive quality experience in student lectures $(2.5 \%)$. The following will discuss each general theme of the quality of student lectures in Jakarta.

Friendship. Friendship is the most positive experience experienced by students in Jakarta. In friendship, the following sub-themes are obtained.

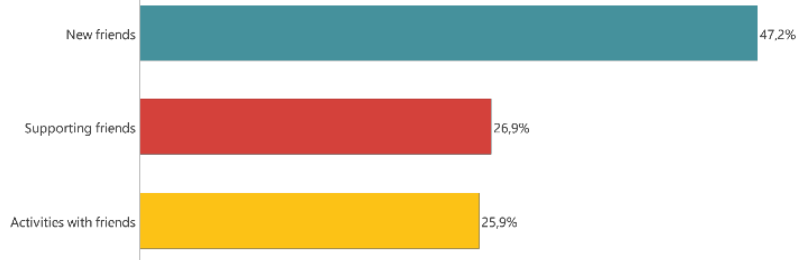

Figure 2 Friendship theme of the college quality of life in Jakarta.

The quality of friendships in lectures is built byenthusiasm in the experience of meeting new friends during lectures (47.2\%), having classmates who carry out social support functions $(26.9 \%)$, and carrying out activities with friends (25.9\%). Friendship is an individual relationship based on the concern of each friend for the welfare of the other party, for the other's goals, and is in some level of closeness. Social connections, friendships within them, are essential for the health and well-being of an individual. People whose social needs are not met have a greater incidence of depression, weaker immune systems, and higher mortality rates than those with close connections [10]. Even brief meetings, whether friends or lovers, provide benefits by enhancing one's positive mood and overall well-being [4].

Acquisition of Knowledge. The study participants felt the quality of their college life along with the experience of gaining knowledge during their studies. Participants feel the atmosphere of the lecture which is certainly different from the atmosphere of other social environments. In addition, the knowledge gained can also be applied in the participants' personal and social lives. Apart from self-enriching knowledge, the knowledge gained during the study is knowledge related to other people. In this case, participants are increasingly able to understand other people around them based on the knowledge they acquire informally through social and formal relationships in lectures.

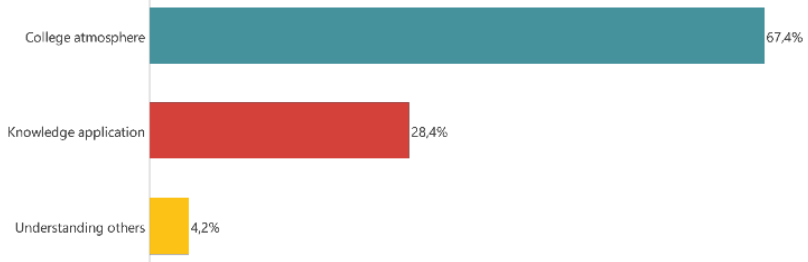

Figure 3 The knowledge acquisition theme of the college quality of life in Jakarta.

The scientific atmosphere during the study was felt by the research participants as a source, especially in obtaining a variety of knowledge (67.4\%) followed by knowledge from the application of knowledge that has been obtained during class learning (28.4\%). Research participants express the application of the knowledge they learn in everyday life as the quality of the lecture climate as follows: "Learn how to solve problems" (participant 9). "There is more to practicum than material" (participant 119). "I can make my college useful for my life" (participant 175). Understanding other people is also a sub-theme found in the theme of acquiring knowledge, as expressed by participant 15: "Understand the different nature of people".

Self-improvement. Self-improvement is a lifelong process. It is a way for people to assess their skills and qualities, consider their goals in life and set goals to realize and maximize their potential. Being in higher education is also a process that exists in self-development. Participants express academic achievement, autonomy, selfunderstanding, and discipline as part of their selfimprovement. The subtheme is summarized in the following figure.

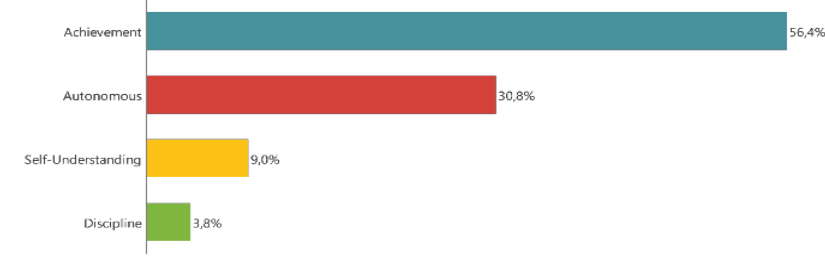

Figure 4 Self-improvement theme of the college quality of life in Jakarta.

Achievement is expressed as a motive to continue to face challenges and achievement from motivated learning outcomes. Quality of class is the 4th theme which is the theme of the college quality of life. In matters related to participant achievement, it is stated as: "Get good grades" (participant 108) "I always want to know more" (participant 123). 
Quality of Class. The college quality in the class is built on the quality of the teacher's attitude (37.5\%), an attractive class atmosphere $(34.4 \%)$, and the teaching skills of the lecturers $(28.1 \%)$. The teacher's attitude is the sub-theme of building the highest class-quality impressions. The effective attitudes and actions that teachers use can make a positive difference in the lives of their students. By examining previous educational experiences, teachers can discuss what they should or should not do with a class of students. The five attitudes and actions that are frequently discussed include caring and kindness from the teacher, willingness to share responsibility in the classroom, genuine sensitivity to student diversity, motivation to provide meaningful learning experiences for all students, and enthusiasm to stimulate student creativity [11].

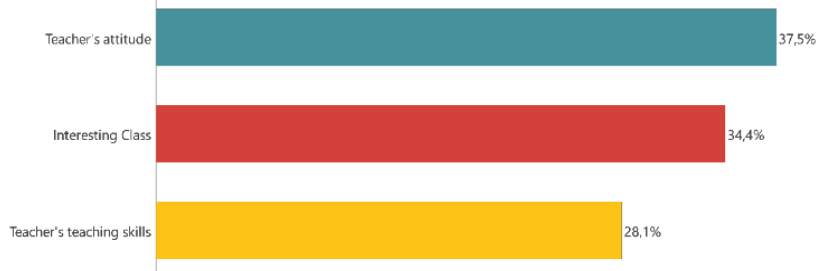

Figure 5 Quality of class theme of the college quality of life in Jakarta.

A positive classroom atmosphere, can as a result of a positive teaching attitude, determines the quality of the class. Five minutes before the lesson ends, students may be impatient waiting for the bell to ring or prepare to be involved in the lesson. Most students are probably familiar with both experiences. Whether a lesson is interesting or not is one of the key dimensions through which students assess their experiences in the classroom. Indeed, the psychological state of being "interested" in the classroom plays a major role in student motivation and learning [12]. Interest has been found to be associated with focused attention, higher cognitive function, and learning [13].

Positive Environment. A positive environment is the 5th theme that describes how the college quality of life climate can be explained by the campus facilities that support and the perception of the new environment.

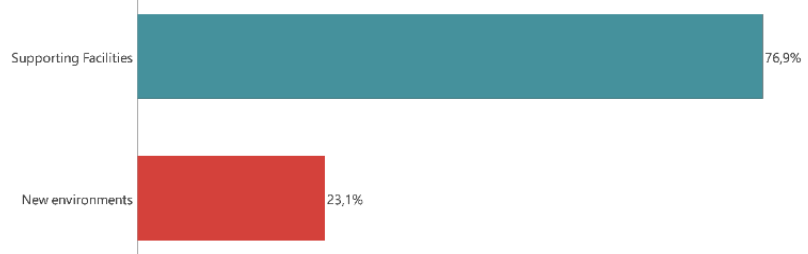

Figure 6 Positive environmental themes in the college quality in Jakarta.

Learning climate is defined as the ethos of expectations and perceptions of teachers, students, parents about themselves, student achievement, the rules and policies of the organization, and the facilities themselves [14]. A researcher designed a perception questionnaire that was used to obtain data from teachers about the effects of building conditions on their performance. Teachers in buildings in poor condition stated that the design and appearance of the facilities had a negative impact on the learning climate. Conversely, teachers in buildings in good condition reported that the building had a positive influence on the learning climate. These findings are supported in this study that the quality of facilities that support lectures adds to the positive perception of the environment that supports the teaching and learning process.

Organizational Dynamics. The quality of the participant lecture climate is also built by the participant's organizational life consisting of leadership (22.2\%) and student organization work programs $(78.8 \%)$. The following figure shows a summary of the sub-themes of organizational dynamics.

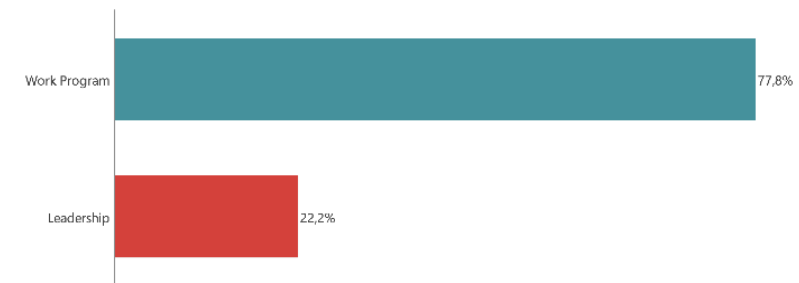

Figure 7 Organizational dynamic themes in the college quality in Jakarta.

The college quality of life is not only about scientific and academic knowledge but also contains the role of organizational dynamics for students. Students can develop leadership skills and also work together in carrying out work programs for student organizations. 25 participants expressed involvement in work programs to assess their quality in their studies on campus: "Work program in the organization". "Participate in fun activities like join in college student organization" (Participant 37). Besides that, leadership is also an interesting thing for participation in completing the quality of their lectures. "A large organization and train the spirit of leadership" (Participants 74). The main aim of educational institutions in providing academic learning to students is to ensure that they can achieve their personal and professional goals, appropriately maintain their livelihood opportunities and turn into effective citizens of the country. Apart from academic learning, students need to develop leadership skills among themselves. When they develop leadership skills, they can lead and guide others in the right direction, instill the traits of perseverance and conscience and distinguish between what is appropriate and what is not. The development of leadership skills among students is an integral part of education. Through the development of leadership skills, individuals can generate awareness in terms of direction, how to practice procedures to carry out various tasks and activities, and achieve desired goals [15]. Thus, the quality of college life is related to various things 
which are not only about scientific and academic knowledge, but also contain social aspects of student life such as organizational dynamics, the environment, and friendship for students.

The results of this study attempted to identify themes related to the initial study of college quality of life among students. This study used open-ended questions related to students' perceptions of college quality of life. Thematic analysis is used in analyzing respondents' answers. Quality of college life not only affects the overall quality of life but also affects the reputation of the college. Quality of college life can affect two aspects, namely the identification of universities and word of mouth [16].

Based on the research findings, several themes are resulting from data processing. Whereas, the quality of college life is related to various things which are not only about scientific and academic knowledge but also contain non-academic aspects. This is following the statement of $\mathrm{Yu}$ and Kim [16] adding two aspects that can affect the quality of college life, namely cognitive and affective aspects. Therefore, this is closely related to the discussion of the theme of friendship which is perceived to be more colorful in the lecture life of the participants in this study. Friendship also means the desire to be with other people, especially when faced with unpleasant experiences. Friendship is also needed to make the learning environment more enjoyable [17].

The results of this study attempted to identify themes related to the initial study of college quality of life among students. This study used open-ended questions related to students' perceptions of college quality of life. Thematic analysis is used in analyzing respondents' answers. Quality of college life not only affects the overall quality of life, but also affects the reputation of the college. Quality of college life can affect two aspects, namely identification of universities and word of mouth [16,18]. According to Yu and Kim [16], higher education identification will be higher if students give recognition to higher education, such as feeling happy when they hear praise about their college or feeling that higher education progress is a personal achievement for these students. Meanwhile, word of mouth can be described through the tendency of students to share positive and negative reviews related to the quality given by higher education, such as when students spread positive comments about higher education with great enthusiasm [18]. Sirgy [18], argues that the cognitive aspect of quality of college life consists of meeting the basic needs of college students. The basic needs of these students include health and security needs, economic and family needs, social needs, self-esteem needs, self-actualization needs, knowledge needs, and aesthetic needs. The affective aspect of the quality of college life according to Diener [16], consists of two components, namely positive affection and negative affection felt by students during the last few months. The feelings contained in positive affection include enthusiasm, interest, determination, passion, inspiration, alert, active, proud, and caring. Negative affection consists of feelings of fear, resentment, depression, anxiety, nervousness, shame, guilt, irritability, and a tendency to have the desire to argue. Based on the research findings, there are a number of themes resulting from data processing. Whereas, the quality of college life is related to various things which are not only about scientific and academic knowledge, but also contain non-academic aspects. This is in accordance with the statement of $\mathrm{Yu}$ and Kim [16] adding two aspects that can affect the quality of college life, namely cognitive and affective aspects. Sirgy [16,18], argues that cognitive aspects that affect the quality of college life include satisfaction with the level of meeting the basic needs of students in tertiary institutions, including health and security, economy and family, social, self-esteem, selfactualization, knowledge, and aesthetics (beauty).

According to Erikson [19] states that the psychosocial stage of early adulthood is characterized by the level of individual intimacy that affects development. The intimacy marked in early adulthood is part of the individual maturity process to find a partner and achieve the desired identity. The process of individual transition from adolescence to early adulthood will be marked by individual wholeness seeking identity. However, not many early adults fail in the process of intimacy and cause individuals to feel lonely and refuse to commit to anyone. The two stages are known as intimacy vs isolation, which is the stage where individuals learn how to interact with other people more deeply. At this stage the individual will be open to others to get to know himself more deeply and form romantic relationships.

\section{CONCLUSIONS}

Based on the results of data processing on the thematic analysis of 213 participants, themes related to the quality of lectures (college quality of life) of students in Jakarta obtained the following findings: (a) friendship is an indicator of the quality of lectures most often experienced, (b) acquisition knowledge, (c) self-development, (d) quality of lectures, (e) positive environment, and (f) organizational dynamics. Thus, the quality of college life is related to various things which are not only about scientific and academic knowledge, but also contain social aspects of student life such as organizational dynamics, the environment and friendship for students.

\section{REFERENCES}

[1] J. W. Santrock, (2012). Life-span development (14th ed.). Dallas: McGraw Hill.

[2] J. M. Sirgy, D. J. Lee, S. Grzeskowiak, G. B. Yu, D. Webb, K. El-Hasan, J. G. Vega, A. Ekici, J. S. Johar, A. Krishen, B. Swoboda, C. B. Claiborne, F. Maggino, D. Rahtz, A. Canto, \& A. Kuruuzum, (2010). Quality of college life (QCL) of students: Further validation of a measure of well-being. Social Indicators Research, 99(3), 375-390. doi: https://doi.org/10.1007/ s11205010-9587-6

[3] M. Benjamin, (1994). The quality of student life: 
Toward a coherent conceptualization. Social Indicators Research, 31(3), 205-264. doi: https://doi.org/10.1007/ BF01078209

[4] S. Arslan, \& O. A. Akkas, (2014). Quality of college life (QCL) of students in Turkey: Student's life satisfaction and identification. Social Indicators Research, 115(2) pp.869-884. doi: https://doi.org/10. 1007/s11205-013-0235-9

[5] K. M. Elliott, (2002). Key determinants of student satisfaction. Journal of College Student Retention: Research, Theory and Practice, 4(3), 271-279. doi: https://doi.org/10.2190/b2v7-r91m-6wxr-kccr

[6] H. G. Yang, \& C. J. Fan, (2017). The perceived effect of quality of life on college learning among Chinese students. Journalism and Mass Communication, 7(6), 334-343. doi: 10.17265/2160-6579/2017.06.005

[7] N. P. Hurley, \& J. Bulcock, (2012). Measurement models of the quality of school life. Retrieved from http://www.mun.ca/educ/faculty/mwatch/Hurley\%20\& \%20Bulcock\%20Measurements\%20Final\%20Nov_\%2014 ,\%202012.pdf

[8] W. E. Martin, J. L. Swartz-Kulstad,, \& M. Madson, (1999). Psychosocial factors that predict the college adjustment of first-year undergraduate students: Implications for college counselors. Journal of College Counseling, 2(2), 121-133. doi: https://doi.org/10.1002/ j.2161-1882.1999.tb00150.x

[9] S. Rankin, \& R. Reason, (2008). Transformational Tapestry Model: A comprehensive approach to transforming campus climate. Journal of Diversity in Higher Education, 1(4), 262-274. https://doi.org/ $10.1037 / \mathrm{a} 0014018$

[10] M. Vaez, \& L. Laflamme, (2003). Health behaviors, self-rated health, and quality of life: A study among first-year Swedish university students. Journal of the American College Health Association, 51(4), 156162. doi: https://doi.org/10.1080/07448480309596344

[11] E. S. Huebner, (1991). Initial development of the student's life satisfaction scale. School Psychology International, 12(3), 231-240. doi: https://doi.org/ $10.1177 / 0143034391123010$

[12] T. Urdan, \& J. C. Turner, (2005). Competence Motivation in the Classroom. In A. J. Elliot \& C. S. Dweck (Eds.), Handbook of competence and motivation (p. 297-317). Guilford Publications

[13] M. Ainley, S. Hidi, \& D. Berndorff, (2002).
Interest, learning, and the psychological processes that mediate their relationship. Journal of Educational Psychology, 94(3), 545-561. https://doi.org/10.1037/ 0022-0663.94.3.545

[14] N. Park, (2004). The role of subjective well-being in positive youth development. Annals of the American Academy of Political and Social Science, 591, 25-39. doi: https://doi.org/10.1177/ 0002716203260078

[15] T. R. Hallenbeck, (1978). College student satisfaction: An indication of institutional vitality - 24 . N.A.S.P.A. Journal, 16(2), 19-24.

[16] G. B. Yu, \& J. H. Kim, (2008). Testing the mediating effect of the quality of college life in the student satisfaction and student loyalty relationship. Applied Research in Quality of Life, 3(1), 1-21. doi: https://doi.org/10.1007/s11482-008-9044-8

[17] C. Satuf, S. Monteiro, H. Pereira, G. Esgalhado, R. M. Afonso, \& M. Loureiro, (2018). The protective effect of job satisfaction in health, happiness, well-being and self-esteem. International Journal of Occupational Safety and Ergonomics, 24(2), 181-189. https://doi.org/10.1080/10803548.2016.1216365

[18] G. B. H. Yu, \& D. J. Lee, (2008). A model of quality of college life (QCL) of students in Korea. Social Indicators Research, 87(2), 269-285. doi: https://doi. org/10.1007/s11205-007-9172-9

[19] D. E. Papalia, \& G. Martorell, (2021). Experience human development (14th ed.). McGraw-Hill. 